Every Heartbeat Matters: Travel Awards for the 2015 AATS Cardiovascular Valve Symposium/Brazil

- Alvaro Albrecht, MD

- Laura Barboza, MD

- Leandro Batisti De Faria, MD

- César Benítez Pozo, MD

- Javier Brenes Gonzalez, MD

- Mariano Martin Candioti Lehmann, MD

- Roque Cordoba, MD

- Dilmar Cunha, MD

- Mauro De Sa, MD

- Thiago Dos Santos, MD

- Renato Faria, MD

- Christian Gonzalo Gil, MD

- Francisco Guzmán Aceituno, MD

- Gustavo Judas, MD

- Debora Klein Ferreira, MD

- Ricardo Liendo, MD

- Gabriel Longo, MD

- Evandro Carlos Lopes, MD

- Ignacio Lugones, MD

- Juan Navas Vasquez, MD

- Marco Antonio Praca Oliveira, MD

- Joao Oliveira, MD

- Cristiano Ourives, MD

- Gilberto Paulozzi Junior, MD

- Mauricio Fortuna Pinheiro, MD

- Fernando Platania, MD

- Virginia Graciela Rivas Arcia, MD

- Emma Salazar Barragán, MD

- Pedro Salerno, MD

- Lucia Salerno, MD

- Carlos Alberto Sancio Junior, MD

- Paulo Cesar Santos, MD

- Rodrigo Segalote, MD

- Renê Silva, MD

- Fabio Silva, MD

- Nicolas Zavaley, MD

\section{AATS Awards Applications}

Now Available at www.aats.org

July 2016 Deadlines

Third John Alexander Research Scholarship 2017-2019 provides an opportunity for research, training, and experience for North American surgeons committed to pursuing an academic career in cardiothoracic surgery.

- Research program must be undertaken within the first three years after completion of an approved North American cardiothoracic residency.

- Applications for the scholarship must be submitted during the candidate's first two years in an academic position.

- The scholarship will begin July 1, 2016, and conclude on June 30, 2018.

- The Scholarship provides an annual stipend of $\$ 80,000$ per year paid to the host institution for direct salary support and related research expenses.

Deadline: July 1, 2016

Evarts A. Graham Memorial Traveling Fellowship, 2017-2018 grants support for training of international surgeons who have been regarded as having the potential for later international thoracic surgical leadership.

- Candidate must be a non-North American who has not had extensive (exceeding a total of six months in duration) clinical training in North America prior to submitting an application.

- Candidate should have completed his/her formal training in general surgery and in thoracic and cardiovascular surgery, but should not have reached a senior position.

- The Fellowship provides a stipend of $\$ 75,000$ US, a major portion of which is intended for living and travel expenses incurred when visiting other medical centers in North America.

Deadline: July 1, 2016

\section{The Western Thoracic Surgical Association}

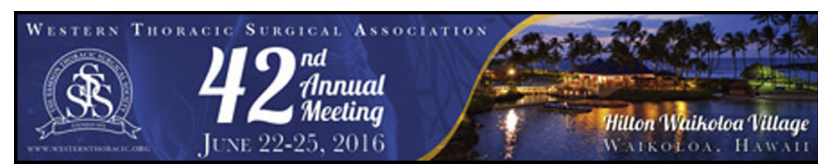

\section{WTSA 42nd Annual Meeting}

June 22-25, 2016

Hilton Waikoloa Village

Waikoloa, Hawaii

Visit the WTSA Web site at www.westernthoracic.org to: 
- Register before the Monday, May 16, 2016, Early Bird deadline, and avoid a \$100 USD increase in most registration fees;

- Reserve your hotel room before the Wednesday, May 18,2016 , housing deadline (although it is possible the block of rooms - or specific room types-set aside for the Western will fill before this cut-off date, so you are strongly encouraged to make your hotel reservations as soon as possible); and

- Receive updates on the latest Annual Meeting program details, venue activities, and local attractions.

\section{PRELIMINARY SCIENTIFIC HIGHLIGHTS}

Thursday, June 23, 2016

Presidential Address

John D. Mitchell, Aurora, CO

Controversies Debate

Concurrent Surgery: Efficient or Unethical?

Friday, June 24, 2016

Breakfast Session*

Public Reporting of Surgeon-Specific Data: Friend or Foe?

Postgraduate Course

War Surgery in Iraq and Afghanistan

Cameron D. Wright, Boston, MA

Saturday, June 25, 2016

\section{Walton Lillehei Point/Counterpoint Session \\ Surgeons on the Heart Team: Quarterbacks or Water Boys?}

\section{SOCIAL HIGHLIGHTS}

Each registration includes access to Wednesday's New Members/Welcome Reception, Thursday's Samson Fun Run and the Legends of Hawaii Luau-Our Big Island Story Theme Dinner, and Saturday's Family Luncheon and President's Banquet. (Registered children, ages 5-18, have access to supervised Children's Receptions during the New Members/Welcome Reception and President's Banquet.)

You may also supplement your Annual Meeting experience with these events:

- Thursday's Ocean Beach Blast*

- Friday's Golf Tournament*

- Friday's Tennis Tournament*

* Separate Registration Required

\section{ACCREDITATION}

This activity is being planned and implemented in accordance with the Essential Areas and Policies of the Accreditation Council for Continuing Medical Education (ACCME) through the joint providership of The American Association for Thoracic Surgery (AATS) and the Western Thoracic
Surgical Association (WTSA). The AATS is accredited by the ACCME to provide continuing medical education for physicians.

This live activity will be designated for AMA PRA Category 1 $\operatorname{Credit}(s)^{\mathrm{TM}}$. Physicians should claim only the credit commensurate with the extent of their participation in the activity.

\section{Applications for Membership}

The WTSA is now accepting Applications for Membership online for Active as well as Candidate membership status. Visit the WTSA Web site at www.westernthoracic.org to read the complete membership eligibility requirements and to initiate an online application.

\section{Active Member}

$\$ 325.00$ annually, plus $\$ 50.00$ initiation fee

Applicant must meet all membership criteria, including but not limited to:

- Reside within or have completed a cardiothoracic residency training program within the geographic limits of the Association.

- Have been engaged in the practice of thoracic and cardiovascular surgery for at least three years following completion of postgraduate training. If a candidate completed his/her thoracic surgical residency or a one-year clinical fellowship in an institution within the geographic limits of the Association, such completion may count towards one of the three years of practice.

- Have a full and unrestricted license to practice medicine in his or her respective state or province, and have a current appointment on the surgical staff of a hospital with no reportable action pending which could adversely affect such applicant's staff privileges at any hospital.

\section{Candidate Member}

$\$ 100.00$ annually

Applicant must meet all membership criteria, including but not limited to:

- Be matched or enrolled in either a cardiothoracic surgery education program accredited by the Residency Review Committee for Thoracic Surgery under the authority of the ACGME or a program approved for cardiothoracic surgery education by the Royal College of Surgeons of Canada - or their equivalency-from within the Association's geographic limits. Individuals who have completed their education in one of the above programs but do not yet meet all of the criteria for Active membership also are eligible to apply for Candidate membership. Individuals who trained outside the Association's geographic limits who are now residing within the Association's boundaries 